\title{
Research on Utilization Status and Potential of Manure Resource in Liaozhong County
}

\author{
Zhigang Wang \\ 1.College of Economics \& Management, Shenyang \\ Agricultural University, Liaoning Shenyang 110866 \\ 2. Institute of Applied Ecology, Chinese Academy of \\ Sciences, Liaoning Shenyang 110016
}

\author{
Jie LV \\ 1.College of Economics \& Management, Shenyang \\ Agricultural University, Liaoning Shenyang 110866
}

\section{Fengming Xi \\ 2. Institute of Applied Ecology, Chinese Academy of Sciences, Liaoning Shenyang 110016}

\begin{abstract}
Based on regional fieldwork and Shenyang statistical yearbook data of aquaculture farmers and organic fertilizer companies, the paper describes the resource utilization status of livestock manure, compare the total nutrients contained in animal manure and chemical fertilizer and analyze a low level of using manure resources and other issues. The results show that: the total manure resources in the study area are $1,292,300 t$, commercialization of organic fertilizer resource accounts for only $8.13 \%$ of the total, the farmers directly buying traditional fertilizers accounts for $55.87 \%$ of the total, idle discard manure $36.00 \%$, organic fertilizer resources waste largely, manure pollution is more serious. From 2006 to 2012 , the amount of the average replacement rate of the nutrients amount contained in manure

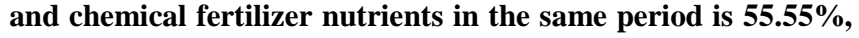
manure resource development potential is huge. Based on this, the paper makes some suggestions.
\end{abstract}

Keywords- Cycle of agriculture, Livestock manure, Resource utilization, Organic fertilizer

\section{INTRODUCTION}

In the past 20 years, Chinese livestock industry producing has grown rapidly, its scale and intensive are becoming more and more, so a lot of manure emissions are worsening environmental pollution and seriously affect human health [1-2]. From 2000 to 2012, China's pork, beef, mutton, milk and egg production have increased by 23.733 million $\mathrm{t}, 29.563$ million $\mathrm{t}$ and 6.792 million $\mathrm{t}$, the growth rate is $39.4 \%, 321.7 \%$ and $31.1 \%$, respectively ${ }^{[3]}$. With the increasing demand for livestock products, the number and size of livestock and poultry industry continues to expand, while emissions from animal manure have increased significantly. In the 1980 s, China's manure production was only 690 million $t$, to 2009 , it has reached 3.264 billion $t^{[4-5]}$. It is predicted that by 2020 , China's manure emissions will reach 4.244 billion $\mathrm{t}^{[6]}$.

In traditional agriculture, livestock and poultry is mainly backyard, organic fertilizer is absorbed by the surrounding farmland, but since the 1960s, organic manure fertilizer gradually replaced the declining proportion of organic fertilizer, a lot of manure is directly discharged with untreated, which caused severe pollution for the surrounding surface and ground water, soil and air, and caused great waste in resources ${ }^{[7-9]}$. For manure resource utilization, many scholars at home and abroad explore in different ways: some scholars analyzed from manure utilization methods, such as fertilizer, feed, fuel and industrial raw materials, some from the utilization of manure treatment technology research, such as drying treatment, deodorization method, incineration and comprehensive treatment method. some estimated from animal manure and energy resource potential evaluation of stock discussed, also some foreign scholars conduct research from livestock and poultry waste management and control methods.

To sum up, most of these studies are from the utilization of methods and techniques, the total estimation and evaluation level of energy potential, in part to analyze the management and monitoring of research, but literatures with comparative analysis of the amount of nutrients contained in the regional animal manure and chemical fertilizers in the same period are not much, especially there is little research analysis from the time perspective of the development potential of manure fertilizer. This paper takes Liaozhong country for example, and study area manure utilization status, and estimates the amount of manure nutrients contained in the stock for the last seven years, making comparative analysis of the use of fertilizers and manure nutrient content.

\section{RESEARCH AREAS AND RESEARCH METHODS}

\section{A. Research objects and research methods}

In this study, the range is livestock and poultry droppings in Liaozhong country, Shenyang City. The unit is country. The main research methods include literature review, field research and comprehensive comparative analysis method to estimate livestock excrement such as the combination of the stock.

\section{B. Basic source of data and parameters}

In this paper, the statistical data are mainly from "Shenyang Agricultural Statistical Yearbook" and "Shenyang Statistical Yearbook", animal health supervision 
and management and the Environmental Protection Agency, the main livestock husbandry from 2006 to 2012 is in Table

1, by contrast analysis of different research scholars to determine the main parameters involved in the estimate. Table 1 Number of main breeding livestock in study area (2006-2012)

\begin{tabular}{llllllll}
\hline \multicolumn{1}{c}{ Breeds } & In 2006 & In 2007 & In 2008 & In 2009 & In 2010 & In 2011 & In 2012 \\
\hline Cow (head) & 234686 & 235477 & 220019 & 295394 & 365981 & 408982 & 438638 \\
Pig (head) & 972983 & 867094 & 810182 & 857860 & 935877 & 1068851 & 1140442 \\
Chicken (hundred) & 162200 & 161400 & 160800 & 167800 & 200885 & 210600 & 229400 \\
\hline
\end{tabular}

C. Estimation of nutrient content and resource stock of manure

1) Number of livestock and breeding cycle

The number of breeding livestock is determined according to their average breeding cycle. General average breeding cycle is less than a year. According to the survey, the majority of the study area cattle farmers are purchased

from Xinjiang and Inner Mongolia and other places, therefore, the average cattle breeding cycle is $150 \mathrm{~d}$, the average pig breeding cycle is $150 \mathrm{~d}$, average broiler breeding cycle is $45 \mathrm{~d}$.

2) Manure excretion coefficient

Combined with field survey data, take the average value as animal manure excretion coefficient, seen in Table 2.

Table 2 Excreta parameter of livestock in study area

\begin{tabular}{lccccc}
\hline Breeds & $\begin{array}{c}\text { Breeding } \\
\text { period }(\mathrm{d})\end{array}$ & $\begin{array}{c}\text { Dailymanure } \\
\text { quantity }(\mathrm{kg})\end{array}$ & $\begin{array}{c}\text { Daily wastewater } \\
\text { quantity }(\mathrm{kg})\end{array}$ & $\begin{array}{c}\text { Period quantity of } \\
\text { solid waste }(\mathrm{t})\end{array}$ & $\begin{array}{c}\text { Period quantity of } \\
\text { wastewater }(\mathrm{t})\end{array}$ \\
\hline Cattle & 150 & 12 & 15.33 & 1.8 & 2.3 \\
Pig & 150 & 2 & 5.33 & 0.3 & 0.8 \\
Broiler & 45 & 0.16 & 0 & 0.007 & 0
\end{tabular}

3) The main nutrient content coefficient of manure

According to the domestic livestock manure for fertilizer content in a variety of major research, take the mean value as the main nutrient content of livestock coefficient (Table 3).

Table 3 Content of main nutrition in livestock manure units: \%

\begin{tabular}{llllll}
\hline \multicolumn{1}{c}{ Breeds } & Organic & $\mathrm{N}$ & $\mathrm{P}_{2} \mathrm{O}_{5}$ & $\mathrm{~K}_{2} \mathrm{O}$ & Water \\
\hline Cow & 12.01 & 0.47 & 0.19 & 0.50 & 81.03 \\
Pig & 10.60 & 1.09 & 0.32 & 0.68 & 74.14 \\
Chicken & 21.58 & 1.41 & 0.90 & 0.78 & 56.00 \\
\hline
\end{tabular}

\section{Calculation Method}

1) Livestock manure excretion estimation

$$
Q_{i j}=N_{i j} C_{i} E_{i}, \quad i=1,2, \cdots, n
$$

Where, $Q_{i j}$ is the fecal excretion of livestock $i$ in year $j, N_{i}$ is the number of breeding of livestock $i$ in year $j$, $C_{i}$ is the breeding cycle of livestock $i, E_{i}$ is excretion coefficient of livestock $i, n$ is the variety number of livestock.
2) The main nutrient content resource estimation of livestock manure

$$
N_{i j}=Q_{i j} \alpha_{i}, \quad i=1,2, \cdots, n
$$

3) Agricultural fertilizer pure volume calculation

$$
Y_{i j}=\sum_{i}^{n} F_{i j} \beta_{i k}, \quad i=1,2, \cdots, n \quad k=1,2,3
$$

\section{RESULTS AND ANALYSIS}

The total amount of animal manure emissions and major nutrient content can be seen in table4: 
Table 4 Production of livestock manure and main nutrient in study area (2006-2012) units: $\mathrm{t}$

\begin{tabular}{|c|c|c|c|c|c|c|}
\hline Year & Breeds & Total & $\mathrm{N}$ & $\mathrm{P}_{2} \mathrm{O}_{5}$ & $\mathrm{~K}_{2} \mathrm{O}$ & Total nutrient \\
\hline \multirow{4}{*}{2006} & Cow dung & 422434.80 & 1964.32 & 788.54 & 2112.17 & 4865.04 \\
\hline & Pig manure & 291894.90 & 3167.06 & 929.20 & 1975.16 & 6071.41 \\
\hline & Fowl dung & 113540.00 & 1602.81 & 1016.18 & 887.50 & 3506.49 \\
\hline & Subtotal & 827869.70 & 6734.19 & 2733.93 & 4974.83 & 14442.95 \\
\hline \multirow{4}{*}{2007} & Cow dung & 423858.60 & 1970.94 & 791.20 & 2119.29 & 4881.44 \\
\hline & Pig manure & 260128.20 & 2822.39 & 828.07 & 1760.20 & 5410.67 \\
\hline & Fowl dung & 112980.00 & 1594.90 & 1011.17 & 883.13 & 3489.20 \\
\hline & Subtotal & 796966.80 & 6388.23 & 2630.45 & 4762.62 & 13781.30 \\
\hline \multirow{4}{*}{2008} & Cow dung & 396034.20 & 1841.56 & 739.26 & 1980.17 & 4560.99 \\
\hline & Pig manure & 243054.60 & 2637.14 & 773.72 & 1644.67 & 5055.54 \\
\hline & Fowl dung & 112560.00 & 1588.97 & 1007.41 & 879.84 & 3476.23 \\
\hline & Subtotal & 751648.80 & 6067.67 & 2520.40 & 4504.68 & 13092.76 \\
\hline \multirow{4}{*}{2009} & Cow dung & 531709.20 & 2472.45 & 992.52 & 2658.55 & 6123.52 \\
\hline & Pig manure & 257358.00 & 2792.33 & 819.26 & 1741.46 & 5353.05 \\
\hline & Fowl dung & 117460.00 & 1658.14 & 1051.27 & 918.15 & 3627.56 \\
\hline & Subtotal & 906527.20 & 6922.93 & 2863.05 & 5318.15 & 15104.12 \\
\hline \multirow{4}{*}{2010} & Cow dung & 658765.80 & 3063.26 & 1229.70 & 3293.83 & 7586.79 \\
\hline & Pig manure & 280763.10 & 3046.28 & 893.76 & 1899.83 & 5839.87 \\
\hline & Fowl dung & 140619.50 & 1985.08 & 1258.54 & 1099.18 & 4342.80 \\
\hline & Subtotal & 1080148.40 & 8094.62 & 3382.00 & 6292.84 & 17769.46 \\
\hline \multirow{4}{*}{2011} & Cow dung & 736167.60 & 3423.18 & 1374.18 & 3680.84 & 8478.20 \\
\hline & Pig manure & 320655.30 & 3479.11 & 1020.75 & 2169.77 & 6669.63 \\
\hline & Fowl dung & 147420.00 & 2081.08 & 1319.41 & 1152.33 & 4552.82 \\
\hline & Subtotal & 1204242.90 & 8983.37 & 3714.34 & 7002.94 & 19700.65 \\
\hline \multirow{4}{*}{2012} & Cow dung & 789548.40 & 3671.40 & 1473.82 & 3947.74 & 9092.97 \\
\hline & Pig manure & 342132.60 & 3712.14 & 1089.12 & 2315.10 & 7116.36 \\
\hline & Fowl dung & 160580.00 & 2266.85 & 1437.19 & 1255.20 & 4959.25 \\
\hline & Subtotal & 1292261.00 & 9650.39 & 4000.14 & 7518.04 & 21168.57 \\
\hline
\end{tabular}

The agricultural chemical fertilizers and pure volume changes can be seen in Table 5:

Table 5 Fertilizer consumption and quantity of pure fertilizer in study area (2006-2012) units: $t$

\begin{tabular}{ccccccc}
\hline \multirow{2}{*}{ Year } & Total & \multicolumn{2}{c}{ quantity of pure fertilizer } & & Total \\
\cline { 3 - 5 } & fertilizer & Nitrogen & Phosphate & Potash & Fertilizer & nutrient \\
\hline 2006 & 113618 & 18045 & 5303 & 3477 & 6638 & 33463 \\
2007 & 93290 & 14603 & 3932 & 2914 & 6279 & 27728 \\
2008 & 91123 & 14065 & 3222 & 4012 & 6445 & 27744 \\
2009 & 96972 & 14746 & 3323 & 4304 & 7225 & 29598 \\
2010 & 97298 & 14701 & 3318 & 4266 & 7409 & 29694 \\
2011 & 97080 & 14690 & 3320 & 4189 & 7406 & 29605 \\
2012 & 97213 & 14851 & 3308 & 4175 & 7310 & 29644 \\
\hline
\end{tabular}

The comparison of fertilizer and manure nutrients and its substitution rate in study area from 2006 to 2012 can be seen in Figure 1, and the way of animal manure using in study area can be seen in Figure 2. 


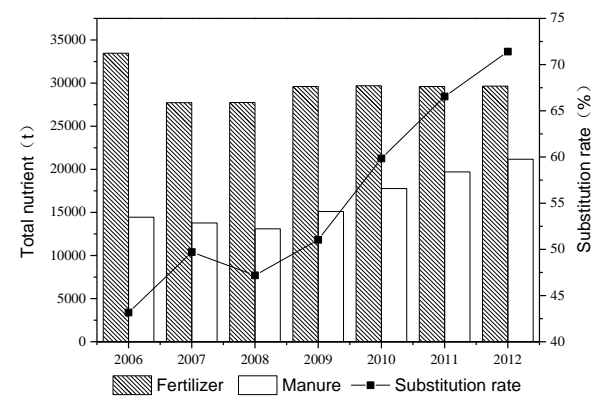

Figure 1 Comparison of fertilizer and manure nutrients and its substitution rate in study area

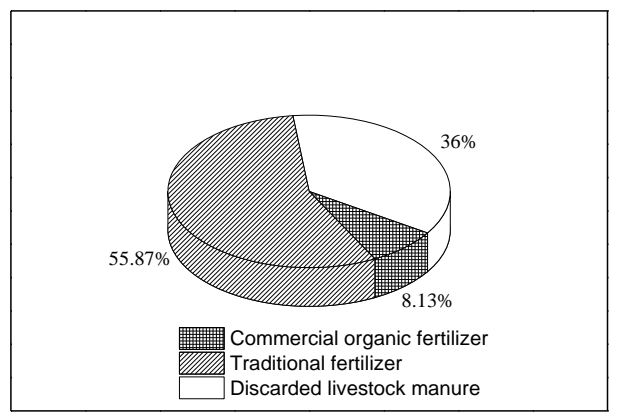

Figure 2 The way of animal manure using in study area

\section{CONCLUSIONS AND SUGGeSTIONS}

\section{A. Conclusions}

(1) The total amount of manure resources in the study area is 1.2923 million $t$, commercialization of organic fertilizer resources accounts for only $8.13 \%$ of the total, the farmers directly buying traditional fertilizers accounts for $55.87 \%$ of the total, idle discard manure $36.00 \%$, organic fertilizer resources waste largely, manure pollution is more serious.

(2) From 2006 to 2012, the amount of the average replacement rate of the nutrients amount contained in manure and chemical fertilizer nutrients in the same period is $55.55 \%$, manure resource development potential is huge.

\section{B. Suggestions}

Based on the above analysis, to make full use of manure resources to promote organic fertilizer industry and sustainable agricultural development, the paper makes the following suggestions: Strengthen the standardization of management in livestock and poultry farms and technical research, and solve key technologies in business of organic fertilizer utilization. Government provide subsidies to make organic fertilizer economy internalize externalities, strengthen organic fertilizer market standardized management, and introduce a series of positive macroeconomic policy guidance.

\section{ACKNOWLEDGEMENT}

Supported by National Natural Science Foundation of China (No.L1222014, 41473076).

\section{References}

[1] Qiu Huanguang, Mo Haixia, Bai Junfei,et al. Livestock Manure Treatment in rural China and its influencing factors: An Empirical Analysis of the survey data in five provinces [J]. Chinese Rural Economy, 2012(3):78-87.

[2] Tian Yishui. Potential Assessment on Biogas Production by Using Livestock Manure of Large-scale farms in China [J]. Transactions of the Chinese Society of Agricultural Engineering, 2012, 28(8):237-241.

[3] National Bureau of Statistics, China Statistical Yearbook 2013[M].China Statistics Press, 2013.

[4] Liu C, Wang F, Shi K, et al. Robust $\mathrm{H} \infty$ Control for Satellite Attitude Control System with Uncertainties and Additive Perturbation[J]. International Journal of Science, 2014, 1(2): 1-9.

[5] Zhang Tian, Bu Meidong, Geng Wei. Pollution Status and Biogasproducing Potential of Livestock and Poultry Excrements in China[J]. Chinese Journal of Ecology,2012, 31(5):1241-1249.

[6] Zhang Suofu. Nutrient Resource Integrated Management Strategies and Technology in China [C]. Chinese Agricultural Science Bulletin, 2006:371-374.

[7] Maria Rosa Teira-esmatges, $X$ Flotats.Livestock Waste Treatment Systems for Environmental Quality, Food Safety, and Sustainability[J].Bioresource Technology,2009,100(22):5527-5536.

[8] Sun Tieheng Song Xueying, Problems on Chinese Agricultural Environment and Countermeasures [J]. Research of Agricultural Modernization, 2008, 29 (6):646-648.

[9] Günther Fischer,Tatiana Ermolieva,Yuri Ermoliev, et al.Livestock Production Planning Under Environmental Risks and Uncertainties [J].Journal of Systems Science and Systems Engineering,2006, 15(4):399-418. 